\title{
Front Matter: Volume 10008
}

, "Front Matter: Volume 10008," Proc. SPIE 10008, Remote Sensing Technologies and Applications in Urban Environments, 1000801 (20 December 2016); doi: 10.1117/12.2264943

SPIE. Event: SPIE Remote Sensing, 2016, Edinburgh, United Kingdom 


\title{
PROCEEDINGS OF SPIE
}

\section{Remote Sensing Technologies and Applications in Urban Environments}

\author{
Thilo Erbertseder \\ Thomas Esch \\ Nektarios Chrysoulakis \\ Editors
}

26-27 September 2016

Edinburgh, United Kingdom

Sponsored by

SPIE

Cooperating Organisations

Innovation Centre for Sensor and Imaging Systems (United Kingdom) - ADS Scotland

(United Kingdom) - The Knowledge Transfer Network (United Kingdom) - Visit Scotland (United Kingdom) • European Regional Development Fund (Belgium) • Technology Scotland (United Kingdom) - European Association of Remote Sensing Companies (Belgium) • European Association of Remote Sensing Laboratories (Germany) - The British Association of Remote Sensing Companies (United Kingdom) • Remote Sensing \& Photogrammetry Society (United Kingdom)

Published by

SPIE

\section{Volume 10008}


The papers in this volume were part of the technical conference cited on the cover and title page. Papers were selected and subject to review by the editors and conference program committee. Some conference presentations may not be available for publication. Additional papers and presentation recordings may be available online in the SPIE Digital Library at SPIEDigitallibrary.org.

The papers reflect the work and thoughts of the authors and are published herein as submitted. The publisher is not responsible for the validity of the information or for any outcomes resulting from reliance thereon.

Please use the following format to cite material from these proceedings:

Author(s), "Title of Paper," in Remote Sensing Technologies and Applications in Urban Environments, edited by Thilo Erbertseder, Thomas Esch, Nektarios Chrysoulakis, Proceedings of SPIE Vol. 10008 (SPIE, Bellingham, WA, 2016) Seven-digit article CID Number.

ISSN: 0277-786X

ISSN: 1996-756X (electronic)

ISBN: 9781510604209

ISBN: 9781510604216 (electronic)

Published by

SPIE

P.O. Box 10, Bellingham, Washington 98227-0010 USA

Telephone +1 3606763290 (Pacific Time) · Fax +1 3606471445

SPIE.org

Copyright @ 2016, Society of Photo-Optical Instrumentation Engineers.

Copying of material in this book for internal or personal use, or for the internal or personal use of specific clients, beyond the fair use provisions granted by the U.S. Copyright Law is authorized by SPIE subject to payment of copying fees. The Transactional Reporting Service base fee for this volume is $\$ 18.00$ per article (or portion thereof), which should be paid directly to the Copyright Clearance Center (CCC), 222 Rosewood Drive, Danvers, MA 01923. Payment may also be made electronically through CCC Online at copyright.com. Other copying for republication, resale, advertising or promotion, or any form of systematic or multiple reproduction of any material in this book is prohibited except with permission in writing from the publisher. The CCC fee code is 0277-786X/16/\$18.00.

Printed in the United States of America.

Publication of record for individual papers is online in the SPIE Digital Library.

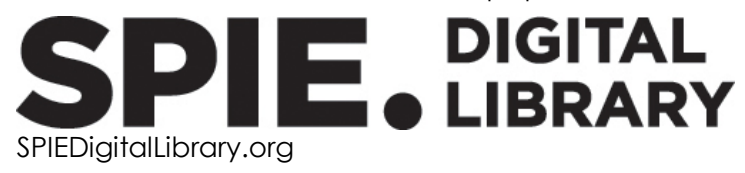

Paper Numbering: Proceedings of SPIE follow an e-First publication model. A unique citation identifier (CID) number is assigned to each article at the time of publication. Utilization of CIDs allows articles to be fully citable as soon as they are published online, and connects the same identifier to all online and print versions of the publication. SPIE uses a seven-digit CID article numbering system structured as follows:

- The first five digits correspond to the SPIE volume number.

- The last two digits indicate publication order within the volume using a Base 36 numbering system employing both numerals and letters. These two-number sets start with $00,01,02,03,04,05$, $06,07,08,09,0 A, 0 B \ldots$. OZ, followed by 10-1Z, 20-2Z, etc. The CID Number appears on each page of the manuscript. 


\title{
Contents
}

\author{
vii Authors \\ ix Conference Committee \\ xi Introduction
}

SESSION 1 URBAN AIR QUALITY

1000802 Improved MODIS aerosol retrieval in urban areas using a land classification approach and empirical orthogonal functions (Invited Paper) [10008-1]

1000803 Pollutant monitoring of aircraft exhaust with multispectral imaging [10008-2]

1000804 Estimation of turbulence production by nocturnal low level jets in Sao Paulo (Brazil)

[10008-3]

1000806 High-grade, compact spectrometers for Earth observation from SmallSats (Invited Paper) [10008-6]

\section{SESSION 2 SMART CITIES}

1000807 Gas detection by using transmittance estimation and segmentation approaches [10008-5]

1000808 Aerial thermography for energy efficiency of buildings: the ChoT project [10008-7]

1000809 Assessing the urban solar energy resource potential of Davao City, Philippines, using LiDAR Digital Surface Model (DSM) and GRASS GIS [10008-8]

10008 OA The measurement of carbon dioxide levels in a city canyon [10008-9]

10008 OB Spatio-temporal analysis of preterm birth in Portugal and its relation with environmental variables [10008-10]

\section{SESSION 3 URBAN CLIMATE}

10008 OC Anthropogenic heat flux estimation from space: results of the first phase of the URBANFLUXES project (Invited Paper) [10008-11]

10008 OD Study on urban heat island effect and its response to the vegetation eco-environmental quality [10008-12]

10008 OE Dynamics of thermal inertia over highly urban city: a case study of Delhi [10008-13] 
$10008 \mathrm{OH} \quad$ Extraction of urban vegetation with Pleiades multiangular images [10008-16]

10008 Ol Evaluation of bispectral LIDAR data for urban vegetation mapping [10008-17]

10008 0J Identifying pure urban image spectra using a learning urban image spectral archive (LUISA) [10008-18]

10008 OK Use of multispectral satellite imagery and hyperspectral endmember libraries for urban land cover mapping at the metropolitan scale [10008-20]

$10008 \mathrm{OL} \quad$ Spectral unmixing of urban land cover using a generic library approach [10008-21]

SESSION 5 URBAN MORPHOLOGY AND INFRASTRUCTURES I

10008 OM Effective delineation of urban flooded areas based on aerial ortho-photo imagery [10008-39]

10008 ON Airborne SAR on circular trajectories to reduce layover and shadow effects of urban scenes [10008-23]

1000800 An improved automated procedure for informal and temporary dwellings detection and enumeration, using mathematical morphology operators on VHR satellite data [10008-47]

\section{SESSION $6 \quad$ URBAN MORPHOLOGY AND INFRASTRUCTURES II}

10008 OP Systematic infrared image quality improvement using deep learning based techniques [10008-24]

$100080 Q \quad$ Building block extraction and classification by means of Markov random fields using aerial imagery and LiDAR data [10008-48]

10008 OR ICARE-HS: atmospheric correction of airborne hyperspectral urban images using 3D information [10008-27]

10008 OS Incremental road discovery from aerial imagery using curvilinear spanning tree (CST) search [10008-28]

10008 OT Automatic pole-like object modeling via 3D part-based analysis of point cloud [10008-42]

SESSION 7 URBAN MORPHOLOGY AND INFRASTRUCTURES III

10008 OU Galaxy: a new state of the art airborne lidar system [10008-29]

10008 OV Identification and correction of road courses by merging successive segments and using improved attributes [10008-30] 
10008 OW Detection of asphalt pavement cracks using remote sensing techniques [10008-31]

10008 0X Tunable mechanical monolithic sensors for real-time broadband monitoring of large civil infrastructures [10008-32]

10008 OY Vehicle detection from very-high-resolution (VHR) aerial imagery using attribute belief propagation (ABP) [10008-33]

POSTER SESSION

$10008 \mathrm{OZ}$ Investigation of air pollution and regional climate change due to anthropogenic aerosols [10008-36]

1000810 Landcover change and light pollution in Kota Bandarlampung [10008-37]

1000811 Improvement of retrieval algorithms for severe air pollution [10008-38]

1000813 Impacts of urban growth and heat waves events on the urban heat island in Bucharest city [10008-43]

1000814 Synergy use of satellite remote sensing and in-situ monitoring data for air pollution impacts on urban climate [10008-44]

1000815 Software for hyperspectral, joint photographic experts group (.JPG), portable network graphics (.PNG) and tagged image file format (.TIFF) segmentation [10008-45]

1000816 Optimization and evaluation of the human fall detection system [10008-46] 
Proc. of SPIE Vol. 10008 1000801-6

Downloaded From: https://www.spiedigitallibrary.org/conference-proceedings-of-spie on 25 Apr 2023 Terms of Use: https://www.spiedigitallibrary.org/terms-of-use 


\title{
Authors
}

Numbers in the index correspond to the last two digits of the six-digit citation identifier (CID) article numbering system used in Proceedings of SPIE. The first four digits reflect the volume number. Base 36 numbering is employed for the last two digits and indicates the order of articles within the volume. Numbers start with 00, 01, 02, 03, 04, 05, 06, 07, 08, 09, OA, OB...0Z, followed by 10-1Z, 20-2Z, etc.

\author{
Agapiou, Athos, OW \\ Alzubi, Hadeel, 16 \\ Alzubi, Raid, 16 \\ Amira, Abbes, 16 \\ Ang, Ma. Rosario Concepcion, 09 \\ Barone, F., OX \\ Berkson, Emily E., 03 \\ Bernardes, J., OB \\ Berwal, Shivesh, OE \\ Beu, Cassia M. L., 04 \\ Boyd, Jenny, OA \\ Bratsolis, Emmanuel, $\mathrm{OQ}$ \\ Briottet, Xavier, OR \\ Bruno, L. S., 15 \\ Budinov, Daniel, OA \\ Bulatov, Dimitri, OV \\ Canters, Frank, OK \\ Casaseca-de-la-Higuera, Pablo, OP \\ Ceamanos, Xavier, OR \\ Çetin, Yasemin Yardımcl, 07 \\ Charou, Eleni, $0 Q$ \\ Chrysoulakis, Nektarios, $0 \mathrm{C}$ \\ Conte, Paolo, 08 \\ Corpetti, Thomas, $\mathrm{OH}, \mathrm{Ol}$ \\ Courty, Nicolas, $\mathrm{OH}$ \\ Cui, Bei, OD \\ Degerickx, Jeroen, OL \\ de Goeij, B. T. G., 06 \\ Del Frate, Fabio, $0 C$ \\ Dida, Adrian I., 13 \\ Esch, Thomas, OC \\ Feigenwinter, Christian, OC \\ Freitas, A., OB \\ Gabey, Andy, OC \\ Gastellu-Etchegorry, Jean-Philippe, 0C \\ Gibson, Ryan, 16 \\ Gilardy, Hugo, OR \\ Giordano, G., OX \\ Gonçalves, H., OB \\ Grimmond, C.S.B., OC \\ Gross, Barry, 02 \\ Guindon, Bert, OM \\ Gür, Yusuf, 07 \\ Habermeyer, Martin, OJ \\ Hadjimitsis, Diofantos G., OW \\ Hafidz, Muhammad, 10 \\ Hartsell, Daryl, OU \\ Häufel, Gisela, OV \\ Hazairin, Azra Q., 10
}

He, Liu, OT

Heiden, Uta, OJ

Hermy, Martin, OL

Hong, Gang, OM

Huang, Yuchun, OS, OT, OY

Hubert-Moy, Laurence, $\mathrm{OH}, \mathrm{O}$

Iordache, Marian-Daniel, OL

Jack, James, OA

Jansen, R., 06

Jenerowicz, Małgorzata, 00

Jilge, Marianne, OJ

Juergens, Carsten, $0 \mathrm{~J}$

Kemper, Thomas, 00

Kitchin, Matthew, OP

Klostermann, Judith, OC

Kumar, Dinesh, $\mathrm{OE}$

Kumar, Krishan, OE

Kumar, Ritesh, OE

Lague, Dimitri, OI

Landier, Lucas, OC

Landulfo, Eduardo, 04

LaRocque, Paul E., OU

Launeau, Patrick, 0 I

Lefebvre, Antoine, $\mathrm{OH}$

Levitan, Nathaniel, 02

Li, Ying, OY

Lindberg, Fredrik, OC

Lucio, A. de C. Jorge, 15

Luo, Chunbo, OP

Mandanici, Emanuele, 08

Marconcini, Mattia, OC

Marques, Márcia T. A., 04

Mende, André, 0J

Messinger, David W., 03

Mettas, Christodoulos, OW

Michon, Cyril, Ol

Mitraka, Zina, OC

Monge-Alvarez, Jesus, OP

Moreira, A. C. de C. A., 04

Mukai, Sonoyo, 0Z, 11

Nabucet, Jean, $\mathrm{OH}, \mathrm{Ol}$

Nakaema, Walter M., 04

Nakata, Makiko, 0Z, 11

Neocleous, Kyriacos, OW

Okujeni, Akpona, OK, OL

Oliveira, M., OB

Olofson, Frans, OC

Ömrüuzun, Fatih, 07

Oosterling, J. A. J., 06 
Özısık Baskurt, Didem, 07

Palm, Stephan, ON

Pandey, Alok Kumar, OE

Parlow, Eberhard, OC

Parmley, Andrew, OP

Pintor, Ben Hur, 09

Pohl, Melanie, OV

Pohl, Nils, ON

Priem, Frederik, OK

Quenol, Herve, 0 I

Ramzan, Naeem, 16

Raymond, Don, OM

Riadini, Fitri, 10

Robinson, lain, OA

Rodrigo, B. P., 15

Rohman, Akmal F., 10

Roussel, Guillaume, OR

Sakagami, Yoshiaki, 04

Sano, Itaru, 0Z, 11

Santos, Pedro A. A., 04

Savastru, Dan M., 13, 14

Savastru, Roxana S., 13, 14

Shahriar, Hasan, 16

Sigelle, Marc, $O Q$

Singh, Vinay Pratap, OE

Snijders, B., 06

Sola, Eula Fae, 09

Somers, Ben, OL

Sommer, Rainer, ON

Stilla, Uwe, ON

Teodoro, Ana C., OB

Teves, Justine, 09

Themistocleous, Kyriacos, OW

Tripp, Jeffrey, OU

van der Linden, Sebastian, OK, OL

van der Wal, L. F., 06

Wang, Guozhi, OS

Wang, Qi, OP

Wang, Yanli, OY

Xie, Rongchang, OS

$\mathrm{XU}$, Saiping, OD

Yang, Haoxiang, OT

Yin, Kai, OD

Zhang, Hongchang, OS

Zhang, Huaizhong, OP

Zhang, Li, OY

Zhang, Xiupeng, OD

Zhang, Ying, OM

Zhao, Qianjun, OD

Zoran, Maria A., 13, 14 


\section{Conference Committee}

Symposium Chair

Klaus Schäfer, (Retired) Karlsruhe Institute of Technology, Institute of Meterology and Climate Research (Germany)

Symposium Co-chairs

Christopher M. U. Neale, University of Nebraska-Lincoln

(United States), Daugherty Water for Food Institute (United States)

Iain H. Woodhouse, The University of Edinburgh (United Kingdom),

Geography and the Lived Environment Research Institute

(United Kingdom)

Conference Chairs

Thilo Erbertseder, Deutsches Zentrum für Luft- und Raumfahrt e.V. (Germany)

Thomas Esch, Deutsches Zentrum für Luft- und Raumfahrt e.V.

(Germany)

Nektarios Chrysoulakis, Foundation for Research and

Technology-Hellas (Greece)

Conference Programme Committee

Matthias Budde, Karlsruhe Institute of Technology (Germany)

Christopher Small, The Earth Institute (United States)

Carlos Tavares Calafate, Universidad Politécnica de Valencia

(Spain)

\section{Session Chairs}

1 Urban Air Quality

Thilo Erbertseder, Deutsches Zentrum für Luft- und Raumfahrt e.V.

(Germany)

2 Smart Cities

Nektarios Chrysoulakis, Foundation for Research and

Technology-Hellas (Greece)

3 Urban Climate

Thilo Erbertseder, Deutsches Zentrum für Luft- und Raumfahrt e.V. (Germany) 
$4 \quad$ Urban Land Cover and Biodiversity

Nektarios Chrysoulakis, Foundation for Research and

Technology-Hellas (Greece)

5 Urban Morphology and Infrastructures I

Thilo Erbertseder, Deutsches Zentrum für Luft- und Raumfahrt e.V. (Germany)

6 Urban Morphology and Infrastructures II

Ying Zhang, Canada Center for Remote Sensing (Canada)

7 Urban Morphology and Infrastructures III

Nektarios Chrysoulakis, Foundation for Research and

Technology-Hellas (Greece) 


\section{Introduction}

The global urbanization constitutes an epochal transformation of the Earth. Since 2007, for the first time in human history more people have lived in cities than in the countryside. According to the United Nations in 2050, around $75 \%$ of the worldwide population will be living in cities. The population density, traffic and infrastructure, environmental and energy problems, climate change, migration, demographic change, aspects of vulnerability and sustainability, new forms of mobility and sharing - unprecedented challenges and opportunities are continuously arising. In any case, the urban environment plays a major role in the development of humanity and the quality of life of the individual citizen.

In respond to this high-interest topic, the conference on Remote Sensing Technologies and Applications for Urban Environments was launched within the SPIE Remote Sensing Symposium held in Edinburgh from 26-29 September 2016. It comprises papers related to advanced remote sensing technologies, applications and information that push beyond the state-of-the-art with respect to urban air quality and climate, urban land cover and biodiversity as well as urban morphology and infrastructures. In 31 oral presentations and 8 posters it was demonstrated that remote sensing offers a wealth of possibilities and opportunities to monitor the urban environment, to support planning processes, to enhance the availability of relevant information, to shape the sustainable city and to improve the quality of life of citizens. The outcome of the conference is documented by the volume of proceedings at hand.

Remote sensing has become a viable technology to monitor and analyze urban air quality and climate, either by space-borne, airborne or ground-based instruments. As an example of the better exploitation of existing instruments, Levitan and Gross present an improved MODIS aerosol retrieval over urban areas, while Mukai et al. show an enhanced algorithm for severe aerosol pollution events. Van der Wal et al. outline a new concept for modular, compact spectrometers and SmallSats designed to monitor urban air pollution at a high spatial resolution. In order to track unburned hydrocarbon emissions from aircraft engine exhaust plumes, Berkson and Messinger propose a multispectral imaging system, while Beu et al. highlight the use of a wind doppler LiDAR to measure the turbulence kinetic energy of low-level jets in Sao Paulo, Brazil. The suitability of Earth Observation data to link air pollution and climate change is shown for East Asian cities (Nakata et al.) and Bucharest, Romania (Savastru et al.). Finally, the need for space-based air pollution data is formulated to better enable epidemiological studies (Oliviera et al.).

The capabilities of remote sensing technologies to make cities smarter and healthier are demonstrated for energy efficiency of buildings (Mandanici and Conte), gas detection (Baskurt et al.), human fall detection (Alzubi et al.) and 
solar energy resource potential (Teves et al.). Boyd et al. present results of measuring carbon dioxide levels in the street canyons and public transport in Edinburgh. The high three-dimensional variability of the gas demonstrates the need for complementary information on air pollution levels in hot spots using mobile devices, micro sensor networks and crowd sourcing. With respect to urban climate, Earth Observation enables a better estimation of the anthropogenic heat flux (Chrysoulakis et al.), the quantification of the urban heat island effect (Xu et al.; Berwal et al.) and the analysis of the impact of urban growth on heat weaves in cities (Zoran et al.).

Advanced urban planning for sustainable and resilient cities relies on information on urban land cover and biodiversity. Latest advances on vegetation mapping in cities are presented by Levebre et al. using Pleiades multi-angular imagery and Nabucet et al. evaluating a bisprectral lidar. The importance of spectral unmixing and the related generic spectral libraries of the endmembers for urban land cover mapping are emphasized in the three papers of Jilge et al., Priem et al. and Degerickx et al.. A neural network is developed for the segmentation of hyperspectral images acquired by drones (Bruno et al.). The relation of land cover change and light pollution is investigated by Rohman et al..

A large number of applications are presented regarding latest results on urban morphology and infrastructures. Remote sensing enables an improved delineation of urban flooded areas (Zhang, Y. et al.), the three-dimensional mapping of buildings and infrastructures by circular synthetic aperture radar (Palm et al.), the mapping of informal and temporal dwellings (Jenerowicz and Kemper), the identification and correction of road courses (Wang et al.; Bulatov et al.) and the detection of asphalt pavement cracks (Mettas et al.). The benefits of synergistic data use are demonstrated by Ceamanos et al. for atmospheric correction of airborne hyperspectral information using a digital surface model and by Bratsolis et al. for building block classification combining aerial imagery and lidar data. While the latter use Markov random fields, attribute belief propagation is used by Wang et al. to detect vehicles in very-high-resolution aerial imagery. A deep learning technique is applied to improve the quality of infrared imagery (Zhang, $\mathrm{H}$. et al.). For the automatic pole-like object modeling a 3D part-based analysis is introduced by He et al. Considering latest developments in remote sensing technology, a sensor for monitoring large civil infrastructures is presented (Barone and Giordano) as well as a new state-of-the-art airborne lidar sytem (Hartsell et al.). 
We, the conference chairs, wish to thank the authors for their valuable contributions, the programme committee for their reviews, and the organizers of the SPIE Remote Sensing 2016 for making this conference possible. A special thank goes to Prof. Klaus Schäfer and Dr. Bob Hainsey for encouraging us to initiate the Conference on Remote Sensing Technologies and Applications for Urban Environments.

Thilo Erbertseder Thomas Esch Nektarios Chrysoulakis 
Proc. of SPIE Vol. 10008 1000801-14

Downloaded From: https://www.spiedigitallibrary.org/conference-proceedings-of-spie on 25 Apr 2023 Terms of Use: https://www.spiedigitallibrary.org/terms-of-use 